\title{
AGE INFLUENCED VARIATIONS IN PLASMA CHOLESTEROL, TESTICULAR CHOLESTEROL AND TESTICULAR ASCORBIC ACID OF PREPUBERTAL TURKEYS (MELEAGRIS GALLOPAVO)
}

\author{
D. V. ARNEJA, D. CHAND, G. C. GEORGIE \\ Department of Animal Production Physiology, Haryana Agricultural University, Hissar - \\ 125004, INDIA
}

Received November 8, 1979

\begin{abstract}
Arneja D. V., D. Chand, G. C. Georgie: Age influenced Variations in Plasma Cholesterol, Testicular Cholesterol and Testicular Ascorbic Acid of Prepubertal Turkeys (Meleagris gallopavo). Acta vet. Brno, 50, 1981: 53-59.

The blood plasma and testicular cholesterol and testicular ascorbic acid concentrations were determined in prepubertal male turkeys at different periods between 135 and 235 days of age and were related to testicular maturation. Plasma cholesterol concentration was negatively correlated with testicular weight $(r=-0.48, P<0.01)$ and showed a decline with age from 8.12 to $3.84 \mathrm{mmol}^{-1}$ during the period. A statistically non-significant decline in testicular cholesterol concentration (101.27 to $40.36 \mu \mathrm{mol} / \mathrm{g}$ wet weight) was observed. The testicular ascorbic acid concentration showed a significant $(P<0.01)$ fall, from 97.7 to $18.5 \mu \mathrm{mol} / \mathrm{g}$ wet weight, between 145 and 175 days of age. During the study period, testicular weight steadily increased from 0.663 to $21.326 \mathrm{~g}$ and showed a size asymmetry with the left testicle being almost double in weight than the right.
\end{abstract}

Maturation, testicular mass.

The relationship of cholesterol concentrations of testicular tissue to maturation and steroidogenesis (Massa and Aoki 1976; I kegwuonu and Aire 1977; Chand et. al. 1978) as well as spermatogenesis (Kanwar et al. 1977) in that tissue have been studied in birds. Attempt has also been made to study the testicular ascorbic acid depletion in phases of increased steroidogenic activity during testicular growth in cockerels (Chand et al. 1978) because of the key role this phenomenon plays in steroidogenesis (Kitabachi 1967). Though changes in testicular weights at different ages have been reported for turkeys (Zidkih 1962; Burke 1973), the authors have not come across reports where estimates of testicular cholesterol or ascorbic acid concentrations have been made and related these to testicular maturation in this species. This paper presents the results of the investigation carried out to establish the age influenced changes in testicular cholesterol and ascorbic acid concentration to testicular growth in turkeys (Meleagris gallopavo), and to enquire into the possibility of existence of a relationship between the levels of these tissue constituents to testicular maturation. Simultaneously, estimates of testicular lipid concentrations were also made and the changes in testicular cholesterol concentrations were related to the total lipid changes of testes. The circulating plasma cholesterol concentration has been correlated to the changes in testicular weight and its cholesterol content, as there are conflicting reports that plasma cholesterol levels are influenced by gonadal activity in birds (Hoffman 1960; Anisko 1974).

\section{Materials and Methods}

Beginning with the age of 135 days, Broad-Breasted Bronze turkey tcms (Meleagris gallopavo) were sacrificed by decapitation in batches of 5 at 135, 145, 175, 195 and 215 days age. At 235 days of age only 4 toms were slaughtered. The schedule of slaughter was discontinued when other toms of the same hatch left with females showed successful mounting which resulted in the production of fertile eggs. Before sacrifice, the live weights were recorded and blocd samples were 
taken in heparinized tubes from wing veins for plasma cholesterol estimation (Zlatkis et al. 1953). The testes were removed immediately after decapitation, cleaned of other tissue debris, blood etc. and weighed to the nearest mg. Either the whole or a fraction weighing not more than $1 \mathrm{~g}$ from the right-side testicle was used for the estimation of testicular ascorbic acid (Dassgupta et al. 1962) after homogenization in $5 \%$ trichloroacetic acid at 1 to $4{ }^{\circ} \mathrm{C}$. Simultaneously, the

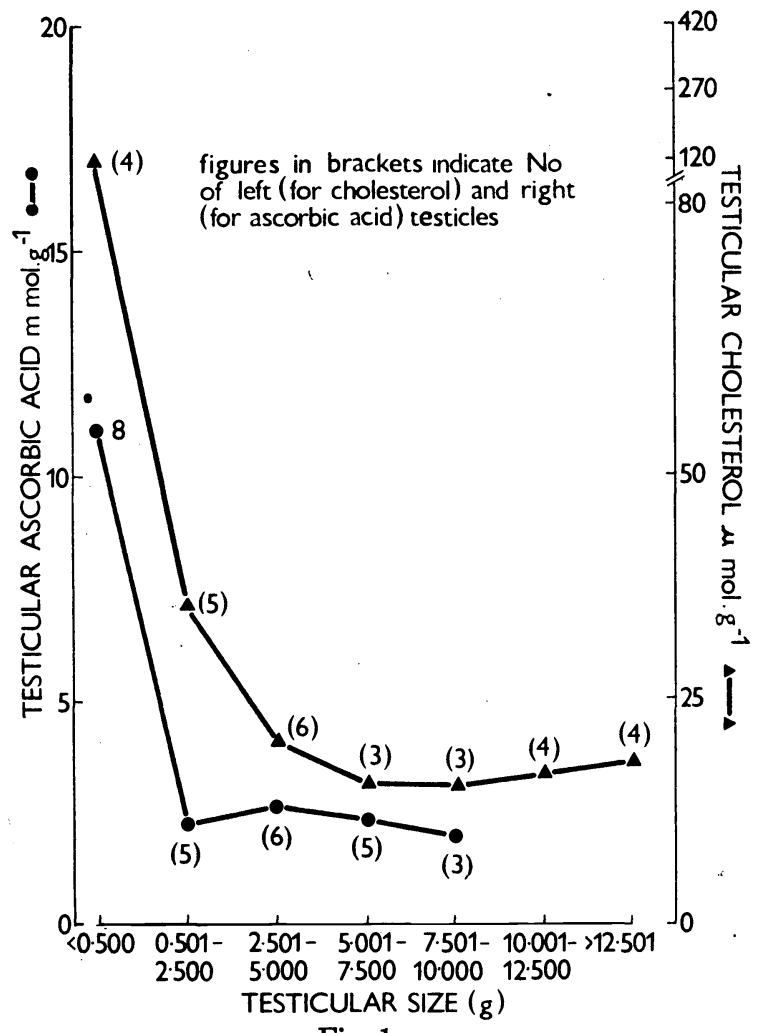

Fig. 1

Mean testicular cholesterol and ascorbic acid concentration at different testicular sizes in turkeys left testicle was utilized for lipid estimation gravimetrically from a chloroform methanol $(2: 1 \mathrm{v} / \mathrm{v})$ extract (Folch et al. 1957). A suitable aliquot of the above lipid extract was used for the estimation of testicular cholesterol (Zlatkis et al. 1953).

\section{Results and Discussion}

\section{Plasma cholesterol}

The average plasma cholesterol levels of the birds at each slaughter and fresh total testes mass are presented in Figure 1. Plasma cholesterol concentration declined from $8.12 \mathrm{mmol} / 1$ at first slaughter at the age of 135 days to $3.84 \mathrm{mmol} / \mathrm{l}$ by the last slaughter at 235 days age. The values obtained in this study were higher than those reported for adult turkey toms (Kirchner et al. 1951) and toms of 13 weeks age (Lisano and Kinnanser 1977). The decrease in the plasma cholesterol was found to be statistically significant $(P<0.01)$. The data obtained

Table 1

Testicular tissue cholesterol (mean \pm S. E.) of turkeys at different ages

\begin{tabular}{|c|c|c|c|}
\hline \multirow{2}{*}{$\begin{array}{l}\text { Age } \\
\text { (d) }\end{array}$} & \multicolumn{3}{|c|}{ Testicular cholesterol } \\
\hline & umol.g $\mathrm{g}^{-1}$ lipid & $\mu$ mol. $\mathrm{g}^{-1}$ testis tissue & Imol/testis \\
\hline 135 & $\begin{array}{c}571.52 \pm 61.318 \\
(22.09)\end{array}$ & $101.27 \pm 51.387$ & $33.57 \pm 7.085$ \\
\hline 145 & $\begin{array}{c}488.71 \pm 118.137 \\
(20.89)\end{array}$ & $40.36 \pm 4.841$ & $41.44 \pm 10.573$ \\
\hline 175 & $\begin{array}{c}494.25 \pm 102.594 \\
(19.10)\end{array}$ & $20.18 \pm 1.533$ & $117.31 \pm 13.421$ \\
\hline 195 & $\begin{array}{c}397.13 \pm 23.638 \\
(15.35)\end{array}$ & $17.46 \pm 1.541$ & $121.30 \pm 32.167$ \\
\hline 215 & $\begin{array}{c}497.43 \pm 52.500 \\
(19.22)\end{array}$ & $16.94 \pm 1.106$ & $201.02 \pm 45.352$ \\
\hline 235 & $388.19 \pm 47.301$ & $15.61 \pm 1.329$ & $225.95 \pm 44.100$ \\
\hline
\end{tabular}

Figures within parenthesis in the 2 nd column indicate the $\%$ cholesterol contained in testicular total lipid. 
in the present study showed that the decline in the level of plasma cholesterol had a definite relationship to the pattern of increment of testicular mass and it became steady, coincident with the achievement of a steady state in the relative mass of testis (Table 3 and Fig. 1). Correlation coefficient ( $r$ ) calculated between testicular mass and plasma cholesterol concentration was - $0.478(P<0.01)$. A low order positive correlation $(\mathrm{r}=0.211)$ also existed between plasma cholesterol and testicular cholesterol concentration. This pattern was definitely at variance with that reported for chicken (Chand et al. 1979) and pigeons (Hoffman 1960) where no such relationship was found. Species differences with respect to role of gonadal hormones in plasma cholesterol regulation definitely exist (Cook 1958) and, therefore, possibility of androsterone bringing about a hypocholesteremic effect, as reported in humans (Hillman et al. 1959) and in some experimental animals (Steinberg 1961), cannot entirely be ruled out in this species as the possible cause of plasma cholesterol drop vis-a-vis testicular growth.

\section{Testicular cholesterol}

The range of cholesterol concentration was very wide, strating at an average of $101.27 \mu \mathrm{mol} / \mathrm{g}$ at 135 days of age to $15.61 \mu \mathrm{mol} / \mathrm{g}$ at 235 days age (Table 1). Analysis of variance conducted on the data revealed non-significant age-induced variability in testicular cholesterol concentration; not surprising because there were very high individual variations in the cholesterol concentration. When the data were regrouped on the basis of testicular mass (as depicted in Fig. 2) without taking age into consideration, analysis of variance still did not indicate significant variation in testicular cholesterol concentration. The testicular cholesterol concentration was more or less similar at all testicular sizes, within a weight range of 0.5 to $12 \mathrm{~g}$, in spite of the clear indication of increase in testicular mass as age advanced (Fig. 1). However, the results of the present study do not preclude the existence of a period having very high testicular cholesterol at ages earlier than 135 days.

In birds with a clear seasonal breeding pattern, accumulation and depletion of cholesterol during changeover from inactive to active testis have been linked to active steroidogenic and spermatogenic activity (Hoffman 1960; Anisko 1974; Kanwar et al. 1977). The clear negative relationship between cholesterol concentration and testicular weight in chicks have been interpreted to mean a clear association of cholesterol depletion to the growth of the testes (Chand et al. 1979). Our observation with turkeys, reported herein, do not lead to such clear interpretation. This, however, does not rule out the existence of such relationships; what might have happened is that the degree of cholesterol depletion in relation to the size of the testicular tissue might be so low that it fails to get reflected in such estimations of total tissue cholesterol concentrations (Johnson et al. 1970). In this species, studies on cellular levels might be more relevant in this connection. Recent studies employing testes of 7-day-old chicks (Massa and Aoki 1976) have shown that stimulation of steroidogenesis by a proper tropic hormone was always accompanied by depletion of cholesterol esters stored in the lipid droplets of the Leydig cells of testes. There is also the possibility that the ratio of cholesterol esters to free cholesterol rather than the total cholesterol per se may be changing (Ikegwuono and Aire 1977). 
Testicular ascorbic acid

The testicular ascorbic acid concentration is given in Table 2 . At the beginning of the study the testicular ascorbic acid was $97.7 \pm 44.6 \mu \mathrm{mol} / \mathrm{g}$ wet mass which

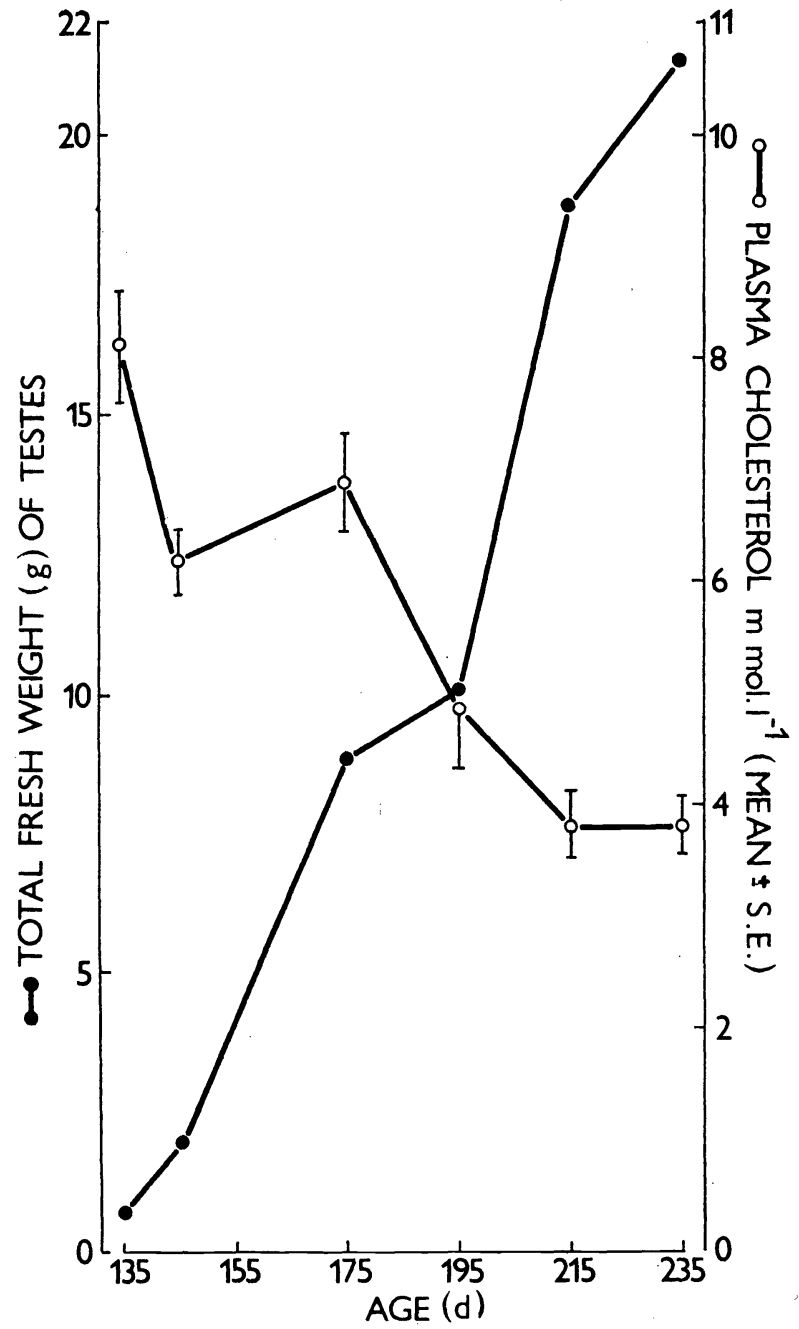
dropped steeply $(P<0.01)$ at the time of 3 rd slaughter by 175 days of age to $18.5 \pm$ \pm 11.9 to $30.6 \pm 39.7$ $\mu \mathrm{mol} / \mathrm{g}$. During this time there was a consistent increase in testicular mass. The results with respect to decline in ascorbic acid and increase in testicular mass agree with the observations reported in chicks (Chand et al. 1978) and rodents (Cos te et al. 1953; Ehmke et al. 1956).

Direct relationship between tissue ascorbic acid depletion and steroidogenesis has been established (Coste et al. 1953; Kitabachi 1867), in the adrenal gland and such a relationship has been postulated to exist in chick testicular tissue (Chand et al. 1978). By this criterion, it may be possible to presume that active testicular steroidogenic process in relation to testicular maturation started be-

Fig. 2

Testicular mass and plasma cholesterol concentration in turkeys at different ages

Table 2

Testicular tissue ascorbic acid (mean \pm S. E.) of turkeys at different ages

\begin{tabular}{|c|c|c|}
\hline \multirow{2}{*}{$\begin{array}{l}\text { Age } \\
\text { (d) }\end{array}$} & \multicolumn{2}{|c|}{ Testicular ascorbic acid } \\
\hline & ( $\mu \mathrm{mol} \cdot \mathrm{g}^{-1}$ testis tissue) & $\mu \mathrm{mol} /$ testis \\
\hline $\begin{array}{l}135 \\
145 \\
175 \\
195 \\
215 \\
235\end{array}$ & $\begin{array}{l}97.74 \pm 44.598 \\
96.09 \pm 18.537 \\
18.51 \pm 1.192 \\
25.04 \pm 1.987 \\
18.26 \pm 3.208 \\
30.63 \pm 3.974\end{array}$ & $\begin{array}{r}64.80 \\
187.57 \\
110.41 \\
270.66 \\
342.12 \\
653.22\end{array}$ \\
\hline
\end{tabular}


tween 145 and 175 days age in turkeys. Because of lack of data for a considerable numbers of days between these two ages, it is not possible to pin-point the exact time of start of ascorbic acid depletion.

Analysis of variance of the data on testicular ascorbic acid concentration after re-grouping according to testicular size (Fig. 2) revealed a significant effect of testicular size $(P<0.01)$. The testicular ascorbate is more or less at similar level at testicular sizes above 0.501 to $2.500 \mathrm{~g}$ (Fig. 1) and testicular sizes smaller than this with high ascorbate levels were present at ages lower than 175 days (Table 3 ).

One would have expected cholesterol depletion to occur around or later to the date of ascorbate depletion, as is the case in chicks (Chand et al. 1978, 1979) because cells in advanced stages of spermatogenesis are implicated in the depletion of cholesterol in the testes (Johns on et al. 1970). The data obtained in present study is at variance with this pattern.

\section{Testicular growth}

The live mass at slaughter, and absolute and relative testicular mass are given in Table 2. The fresh total mass of testes is given in Fig 1. There was a marked asymmetry in the size of the right and left testicle $(P<0.01)$, the average mass of the left testis being more or less double than that of the right one at all ages. Asymmetry in testicular size in turkeys have been reported with left testicle being larger (Zidkih 1962; Burke 1973). The testicular size started to attain a definite and steady proportion to the body mass by 215 days of age (Table 3 ), when the testes reached their maximum relative size and any further growth was isometric with body mass. This, perhaps, is an indication that testicular size has come to adult proportions by this age. The reported testicular mass in adult Broad Breasted White toms is $17.2 \mathrm{~g}$ (Anisko 1974) in comparison to $21.326 \mathrm{~g}$ at 235 days age observed in the Brown toms in present study.

Table 3

Mean ( \pm S. E.) body and testicular mass at different ages

\begin{tabular}{|c|c|c|c|c|}
\hline \multirow[b]{2}{*}{$\begin{array}{l}\text { Age } \\
\text { (d) }\end{array}$} & \multirow[b]{2}{*}{$\begin{array}{l}\text { Live mass } \\
(\mathrm{kg})\end{array}$} & \multicolumn{2}{|c|}{ Testes mass } & \multirow{2}{*}{$\begin{array}{l}\text { Testes mass } \\
\text { (\% body mass) }\end{array}$} \\
\hline & & $\begin{array}{l}\text { Right testicle } \\
(\mathrm{g})\end{array}$ & $\begin{array}{l}\text { Left testicle } \\
\text { (g) }\end{array}$ & \\
\hline $\begin{array}{l}135 \\
145 \\
175 \\
195 \\
215 \\
235\end{array}$ & $\begin{array}{l}4.1 \pm 0.08 \\
4.7 \pm 0.28 \\
7.0 \pm 0.22 \\
7.2 \pm 0.19 \\
8.4 \pm 0.18 \\
9.7 \pm 0.17\end{array}$ & $\begin{array}{l}0.20 \pm 0.043 \\
0.64 \pm 0.310 \\
2.86 \pm 0.617 \\
3.97 \pm 0.786 \\
6.61 \pm 1.548 \\
7.09 \pm 0.942\end{array}$ & $\begin{array}{r}0.46 \pm 0.128 \\
1.32 \pm 0.476 \\
5.96 \pm 0.685 \\
6.84 \pm 1.262 \\
12.13 \pm 2.492 \\
14.23 \pm 2.370\end{array}$ & $\begin{array}{l}0.02 \\
0.04 \\
0.13 \\
0.17 \\
0.22 \\
0.22\end{array}$ \\
\hline
\end{tabular}

\section{Věkové změny cholesterolu v krevní plazmě a kyseliny askorbové a cho- lesterolu v testes prepubertálních krocanů (Meleagris gallopavo)}

V krevní plazmě a testikulární tkáni krocanů 135 až 235 dnů starých byla stanovena koncentrace cholesterolu a $\mathrm{v}$ testes $\mathrm{i}$ koncentrace kyseliny askorbové. Koncentrace cholesterolu $\mathrm{v}$ plazmě byla $\mathrm{v}$ negativní korelaci s hmotností varlat $(\mathrm{r}=$ $=-0.48, P<0.01$ ) a klesala $\mathrm{s}$ věkem z 8.12 na $3.84 \mathrm{mmol}^{-1} \mathrm{1}^{-1}$. Ve varlatech nevýznamně poklesla ze 101.27 na $40.36 \mu \mathrm{mol} / \mathrm{g}$ mokré váhy. Koncentrace ky- 
seliny askorbové ve varlatech krocanů 145 až 175 dnů starých významně $(P<0.01)$ klesla z $97.7 \mathrm{na} 18.5 \mu \mathrm{mol} / \mathrm{g}$ mokré váhy. Hmotnost varlat vzrostla z $0.66 \mathrm{na} 21.33 \mathrm{~g}$, přičemž levé varle dosáhlo hmotnosti téměř dvojnásobné než pravé.

\section{Возникающие с возрастом вариации уровня холестерина в плазме и холестерина и аскорбиновой кислоты в семенниках малолетних индюков}

Был определен уровень холестерина в плазме, уровень холестерина и аскорбиновой кислоты в семенниках малолетних индюков и проводились наблюдения их в связи с созреванием семенников. Уровень холестерина отличается отрицательной связью с весом семенника $(=-0,48, \mathrm{P}<$ $<0,01)$. Уровень холестерина повышается с созреванием семенника с 313,9 до 148,3 мг/100 мл. Наблюдалось значительное понижение уровня жира семенника (с 123,9 до $21,3 \mathrm{m \Gamma} /$ г) и акскорбиновой кислоты (с 1,721 до 0,326 $\mathrm{M \Gamma} / \Gamma)$, а также незначительное понижение уровня холестерина семенника (с 39,2 до $6,6 \mathrm{mг} / \Gamma$ ) в возрастном пределе $145-175$ дней. В тот же период вес семенников увеличился с 0,663 до 21,33 г, при этом левый семенник был почти в двое больше по размеру, чем правый семенник.

\section{References}

ANISKO, E. N.: Relationship among physiological semen characters, body weight and testis weight and volume of turkeys. Sbornik Nauchnykh Trudov. Belorusskays Sel'skokhozyaistvennya Akad. No. 130: 1974 pp 60-63. fide Anim. Breed Abstr., 45, 1977: 5670.

BARTKE, A.: Effect of prolactin and luteinizing hormone on the cholesterol stores in the mouse testis. J. Endocrinol., 29, 1971: 317-324.

BIERI, J. G. - PRIVAL, E. L.: Lipid composition of testis of various species. Comp. Biochem. Physiol., 15, 1965: 275.

BURKE, W. H.: Testicular asymmetry in the turkey. Poultry Sci., 52, 1973: 1652-1654.

CHAND, D. - ARNEJA, D. V. - ARORA, K. L.: Relation of testicular ascorbic acid concentration to testicular development in Desi and White Leghorn poultry. Indian J. Exptl. Biol., 16, 1978: $676-678$.

CHAND, D. - ARORA, K. L. - ARNEJA, D. V.: Cholesterol changes during testicular development in Desi and White Leghorn breeds of poultry. Indian J. Exptl. Biol., 17, 1979: 82-84.

COOK, R. P.: Cholesterol: Chemistry, Biochemistry and Pathology. Academic Press, New York.

COSTE, F. - DEIBARRE, F. - LACRONIQUE, F.: Variations in the level of ascorbic acid in the endocrine glands after stimulation of anterior pituitary. Level of ascorbic acid in the testis of the rat as a function of age. C. R. Soc. Biol., 147, 1953: 608-611.

DASSGUPTA, P. R. - PRAHLAD, K. V. - DHAR, C.: A rapid method of estimation of ascorbic acid in tissues. Current Sci., 31, 1962: 332-333.

EHMKE D. A. - DAVEY, B. L. - TODHUNTER, E. N.: The influence of age and diet on ascorbic acid metabolism in rats. J. Nutr., 58, 1956: 281 -290.

FOLCH, J. - LESS, M. - SLOANE-STANLEY, G. H.: A simple method for the isolation and purification of total lipids from animal tissues. J. Biol. Chem., 226, 1957: 497-509.

HALIMAN, L. - BRADLOW, H. L. - ZUMOFF, B. - FUKUSHIMA, D. K. - GALLAGHER, T. F.: Thyroid - androgen relationship and the hypocholesteric effect of androsterone. J. Clin. Endocrinol. Metab., 19, 1959: 936-948.

HILTON, F. K.: Relationships of testicular cholesterol to hormonal activity and behaviour in the starling. Proc. Soc. exptl. Biol. Med., 107, 1961: 635-655.

HOFFMAN, R. A.: Observations on serum and gonad cholesterol in pigeons. Endocrinol., 67, 1960: $311-318$.

IKEGWUONU, F. I. - AIRE, T. A.: Age influenced variations in levels of cholesterol and ATPase activity in the testes of prepubertal chicks. Poultry Sci., 56, 1977: 1158-1160.

JOHNSON, A. D. - GOMES, W. R. - VANDEMARK, N. L.: The testis. Vol. II. Academic Press, New York Pp 193-258. 
KANWAR, U. - SHEIKHER, C. - MEHTA, H. S.: Seasonal changes in the lipids of the crow Corvus splendeus: Cytochemical and biochemical studies. Indian J. Exptl. Biol., 15, 1977: $1040-1042$.

KIRCHNER, N. - PRITHAM, G. H. - BRESSLER, G. D. - GORDEUK, S. (Jr.): Composition of normal turkey blood. Poultry Sci., 30, 1951: 875-879.

KITABACHI, A. E.: Ascorbic acid in steroidogenesis. Nature, Lond., 215, 1967: 1385-1386.

LISANO, M. E. - KINNAMER, J. E.: Values for several blood parameters in Eastern Wild turkeys. Poultry Sci., 56, 1977: 157-166.

MASSA, E. M. - AOKI, A.: Differentiation of cholesterol compartments in the immature chick testis. J. Reprod. Fertil., 47, 1976: 313-318.

STEINBERG, D.: Chemotherapeutic approaches to the problem of hyperlipidemia. Advan. Pharmacol. 1, 1962: 59-161.

ZIDKIH, Z. A.: Changes due to age in the internal organs of Moscow Bronze turkeys. Izv. Timirjazev. Sel.-hoz. Akad. 6: 1962, 227-230. fide Anim. Breed. Abstr. 31, 1963: 2522.

ZLATKIS, A. - ZAK, B. - BOYLE, A. J.: A new method for the direct determination of serum cholesterol. J. Lab. Clin. Med., 41, 1953: 486-492. 